\title{
Recombinant Prothymosin Alpha
}

National Cancer Institute

\section{Source}

National Cancer Institute. Recombinant Prothymosin Alpha. NCI Thesaurus. Code C1203.

A recombinant form of the endogenous polypeptide hormone that exerts

immunomodulatory effects primarily on mononuclear cells. Prothymosin alpha

stimulates the production of various cytokines including granulocyte/macrophage colony stimulating factor (GM-CSF) alpha, gamma interferon (IFN) and interleukins such as IL-2. This agent may also increase some tumor antigens expression, thus inducing better $T$ lymphocyte responses to tumor cells. Combined with chemotherapy, prothymosin alpha may exhibit significant anti-tumor effects. This agent also helps to regenerate lymph node and bone marrow cells after treatment with certain toxic chemotherapeutics.

( $\mathrm{NCl04)}$ 